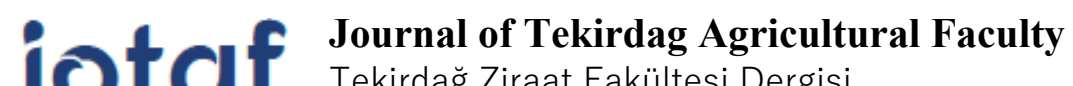 \\ Tekirdağ Ziraat Fakültesi Dergisi
}

\section{Farklı Konukçu Bitkilerden İzole Edilen Agrobacterium tumefaciens İzolatlarının Fenotipik ve Genotipik Karakterizasyonu}

Isolation and Identification of Agrobacterium tumefaciens Strains From Different Hosts In Turkey

\author{
Eda GEYLANİ YÜZBAŞIOĞLU ${ }^{1}$, Yeşim AYSAN ${ }^{2}$
}

\section{Özet}

Bu çalışmada, 2008-2011 yılları boyunca 4 farklı ilde 10 farklı konukçu bitkiden tipik ur belirtisi gösteren enfekteli bitki örnekleri toplanmıştır. Toplanan enfekteli bitki dokularından toplam 174 bakteri izolatı elde edilmiştir. Elde edilen izolatların patojenisite testlemeleri havuç (Daucus carota L.) dilimi, kalonşe (Kalanchoe daigremontiana), domates (Solanum lycopersicum L.) ve ayçiçeği (Helianthus annus L.) fideleri üzerinde yapılmıştır. Patojenisite testleri sonucunda 414 re-izolat elde edilmiş olup, bu izolatlar arasından 138 re-izolat detaylı çalışmalarda kullanılmak üzere seçilmiştir. Seçilmiş olan tüm izolatlar klasik ve moleküler yöntemlerin sonuçlarına göre Agrobacterium tumefaciens olarak teşhis edilmiştir. Test edilen 138 izolat ve 6 referans izolatın tamamı kalonşe bitkisi ve havuç dilimi üzerinde tipik ur belirtilerine neden olurken, bu izolatlar arasından 67 izolat domates bitkisinde, 61 izolat ise ayçiçeği bitkisi üzerinde tipik ur belirtisi oluşturamamıştır. Bu tez kapsamında 3-ketolaktoz üretimi, \% 2'lik $\mathrm{NaCl}^{\prime}$ de büyüme, $35^{\circ} \mathrm{C}$ 'de gelişme, litmus milk'de reaksiyon, eritritol ve melezitozdan asit oluşturma, malonik asit, L-tartarik asit ve mucic asitten alkali oluşturma, demir amonyum sitrat kullanımı, sitrat kullanımı, $\mathrm{PDA}+\mathrm{CaCO}_{3}$ besiyerinde asit temizleme, potasyum hidroksit testiyle gram reaksiyon ve oksidaz testi kullanılmıştır Yapılan morfolojik, fizyolojik ve biyokimyasal testlere göre, test edilen izolatlardan 3 tanesi dışında, izolatlar arasında önemli farklılı gözlenmemiştir. Bu izolardaki farklılıkta sözkonusul38 izolat arasından 48 izolat detaylı çalışmalar için seçilmiş, genetik profilleri REP PCR, ERIC PCR, BOX PCR ve RFLP teknikleri kullanılarak analiz edilmiştir. Bildiğimiz kadarıyla, şeftali, erik, kiraz, armut, trabzon hurması, meşe ve kalonşe bitkilerinden bu etmenin ülkemizdeki varlığı ilk kez bu çalışmayla ortaya konmuştur. Elde edilen sonuçlar farklı konukçulardan elde edilen Agrobacterium. tumefaciens izolatlarının benzerlik ve farklılıklarını ortaya koymuştur. Sonuç olarak, 5 ana grupta, 8 farklı küme ve 26 özgün profile sahip 34 genotip belirlenmiştir. İzolatlar ile konukçu bitki ve coğrafik bölge arasında ilişsi kurulamamıştır.

Anahtar Kelimeler: Agrobacterium tumefaciens, Patojenite testleri, Spesifik PCR, Genetik profilleme, RFLP

\footnotetext{
1*Sorumlu Yazar/Corresponding Author: Eda Geylani Yüzbaşioğlu, Biyolojik Mücadele Araştırma Enstitüsü, Adana-Türkiye E-mail: eda.yuzbasioglu@tarimorman.gov.tr (D) OrcID: 0000-0002-33864476

${ }^{2}$ YYeşim Aysan, Çukurova Üniversitesi, Ziraat Fakültesi, Bitki Koruma Bölümü, Adana-Türkiye. Email: aysanys@cu.edu.tr (DD OrcID: 0000-0003-2647-5111. Atıf/Citation: Geylani Yüzbaşıoglu E., Aysan Y. Farklı Konukçu Bitkilerden İzole Edilen Agrobacterium tumefaciens İzolatlarının Fenotipik ve Genotipik Karakterizasyonu. Tekirdăg Ziraat Fakültesi Dergisi, 18 (2), 247-259. 


\begin{abstract}
During 2008-2011 growing season, 148 infected plant samples, showing tumor (gall) symptom, were collected from ten different host plants in 4 different province of Turkey. Total of 174 bacterial isolates were obtained from infected samples. Pathogenicity tests were conducted on carrot (Daucus carota L.) slice, kalonche (Kalanchoe daigremontiana), tomato (Solanum lycopersicum L.) and sunflower (Helianthus annus L.) seedlings. From pathogenicity tests, 414 isolates were re-isolated and total of 138 bacterial re-isolates were selected and used in further studies. All these selected isolates were identified as Agrobacterium tumefaciens according to classical and molecular identification tests. Although all 138 isolates caused typical galls on kalonche and carrot slices, 67 isolates on tomato and 61 isolates on sunflower seedlings were failed to cause typical gall symptoms. In the study, 3 -ketolactose production, growth in $2 \% \mathrm{NaCl}$, development at $35^{\circ} \mathrm{C}$, reaction in litmus milk, acid formation from erythritol and hybridis, alkali formation from malonic acid, L-tartaric acid and mucic acid, use of iron ammonium citrate, use of citrate, acid clearing in $\mathrm{PDA}+\mathrm{CaCO} 3$ medium, gram reaction with potassium hydroxide test and oxidase test were used. Apart from three isolates, no major differences were observed among the bacterial isolates tested according to morphological, physiological and biochemical tests. Among these 138 isolates, 48 bacterial isolates were selected and their genetic profiles were analyzed by using REP PCR, ERIC PCR, BOX PCR and RFLP techniques. As far as we know, peach, plum, cherry, pear, persimmon, oak and kalonchoe from the plants in our country, the presence of these factors has been demonstrated in this study for the first time. This study clearly showed the differences and similarities of the bacterial isolates of Agrobacterium tumefaciens obtained from different host plants. As a result, 34 genotypes in 5 main group and 8 different clusters, 26 unique profiles were determined. With isolates of different host plants and geographic areas can be concluded that the relationship between the genotyped.
\end{abstract}

Keywords: Agrobacterium tumefaciens, Pathogenicity tests, Specific PCR, Genetic profiling, RFLP 


\section{Giriş}

Türkiye, özellikle bazı meyve türlerinin üretiminde önemli bir konumda bulunmaktadır (Tablo1). Kayısı ve kiraz üretiminde dünya sıralamasında ilk sıradaki yerini uzun yıllardır korumaktadır. Diğer birçok meyvenin üretiminde ise dünya çapında ilk 10 sıralamasındadır (Anonim, 2011). Ülkemiz, çok çeşitli ekolojik özellikler bakımından süs bitkileri yetiştiriciliğine de son derece uygundur. Aynı zamanda birçok süs bitkisinin gen kaynağıdır. Bu nedenle, kesme çiçek üretimi başta olmak üzere, dış mekan süs bitkilerinde yeni türlerin üretimi ve ihracatı üzerinde çalışılmaktadır. Gül üretimi ise 2012 yılında \% 6.1 oranında artarak süs bitkileri arasında \% 10.4'e ulaşmıştır (Anonim, 2012).

Tablo1. Türkiye'de bazı meyve türlerinin üretim miktarları (Anonim, 2011)

Table1. Production means of some fruit species in Turkey (Anonim, 2011)

\begin{tabular}{ll}
\hline Ürün & Üretim (Milyon Ton) \\
\hline Elma & 2.680 .075 \\
Kayıs1 & 676.138 \\
Şeftali & 545.902 \\
Kiraz & 438.550 \\
Armut & 286.382 \\
Erik & 268.696 \\
Trabzon hurmas1 & 28.295 \\
\hline
\end{tabular}

Meyve fidancılığında ekonomik kayba neden olan birçok hastalık etmeni vardır. Bu hastalıklar içinde en önemlilerinden biri de kök ve kök boğazı uru hastalığına sebep olan Rhizobium radiobacter (Agrobacterium tumefaciens, Smith ve Townsend, 1907) adlı bakteriyel etmendir (Lippincot ve ark, 1980). Son yıllarda taksonomide meydana gelen değişimlerden Agrobacterium cinsi de etkilenmiştir. Bu cins içerisinde yer alan türlerin bir kısmı Rhizobium cinsine dahil edilmiştir (Slater ve ark., 2009).

Kök ve kök boğazı uru hastalığı tüm dünyada yaygın olarak görülmekte ve bir çok üründe ekonomik kayıplara neden olmaktadır. Özellikle fidanlıklarda etkili olan bu hastalık, enfekteli bitkilerin pazarlanabilirliğini ortadan kaldırmaktadır (Lippincott ve ark., 1983). Hastalık etmeni olan Agrobacterium tümefaciens, gram negatif, toprak kökenli bir bakteri olup genellikle dikotiledon, bazen de monokotiledonlarda olmak üzere 93 farklı familyadan 643 konukçuda ur oluşturabilmektedir. Hastalık etmenin, en yaygın olarak görüldüğü bitki türlerinin başında, kiraz, şeftali, vişne, erik gibi sert çekirdekli meyveler; elma, armut gibi yumuşak çekirdekli meyveler; ceviz, badem gibi sert kabuklu meyveler; asma ve çeşitli süs bitkileri gelmektedir ( Lippincott ve Lippincott, 1975; De Cleene ve De Ley, 1976).

Ülkemizde hastalığın sert ve yumuşak çekirdekli meyve ağaçlarında varlığı çok uzun yıllardan beri bilinmektedir. Karaca (1977)' nin bildirdiğine göre hastalık ilk defa İzmir'de şeftali, erik ve ayva ağaçlarında, sonra Edirne'de vişne, elma ve armut ağaçlarında görülmüştür. Daha sonra yapılan araştırmalar hastalığın Türkiye'nin hemen her yöresinde mevcut olduğunu ortaya koymuştur. Ege Üniversitesi'nde yapılan bir doktora çalışmasında Öden (1991) İstanbul ve İzmir illerinde süs bitkilerinde yaptığı incelemelerde Chrysanthemum spp. (Krizantem) ve Rosa spp. (Gül)'da Agrobacterium tumefaciens'in neden olduğu kök boğazı uru hastalığının varlığını saptamıştır. Doğu Akdeniz bölgesinde 2000'li yılların başlarında ise Aysan ve Şahin (2003) tarafından güllerde Agrobacterium tumefaciens' in neden olduğu bir hastalık epidemisi rapor edilmiştir. Aynı yıllarda Aysan ve ark., (2003) Ninfa çeşidi kayısılarda (Prunus armeniaca) Agrobacterium tumefaciens'in neden olduğu kök ve kök boğazı uru hastalığına dikkat çekmiş ve Doğu Akdeniz bölgesinde yayıldığını bildirmiştir. Bozkurt ve Soylu (2011), Hatay ili elma bahçelerinde kök boğazı uru hastalığının belirlenmesi ile ilgili bir çalışma yapmışlardır. Ayrıca etmenin endofitik ve epifitik bakteriler ile mücadelesi ilgili bir çalışmaları da bulunmaktadır (Soylu ve Bozkurt, 2019).

Gıda, Tarım ve Hayvancılık Bakanlığı'nın teknik talimatnamesine göre, 2006 yılına kadar Agrobacterium tumefaciens, toleransı sıfır, çok tehlikeli ve hızla yayılan karantina etmenleri arasında yer almaktaydı (Anonim, 2006). Hastalık etmeni, bu yıldan sonra, ülkemizde yaygın olarak bulunduğu gerekçesiyle karantina listesinden çıkarılmıştır. Agrobacterium vitis ise halen karantina listesinde yer almaktadır (Zirai Karantina Yönetmeliği, 2009). 
Geylani Yüzbaşıoglu \& Aysan Farklı Konukçu Bitkilerden İzole Edilen Agrobacterium tumefaciens İzolatlarının Fenotipik ve Genotipik Karakterizasyonu

Hastalığın özellikle bulaşık üretim materyali ile temiz bölge ve ülkelere taşındığı bilinmektedir. Bu nedenle en önemli tedbirlerden biri de hastalıksız üretim materyali kullanmaktır (Peluso ve ark., 2003). Hastalığın dünyadaki durumu, yayılışı, konukçu dizini üzerine pek çok çalışma yapılmıştır. Ülkemizde de hastalığın varlığı ve tanısı üzerine çalışmalar bulunmaktadır. Ancak, meyve bahçelerinden ve fidan üretim alanlarından elde edilen Agrobacterium tumefaciens izolatlarının yıllara, izole edildiği konukçuya, yöreye ve yere (bahçe veya fidanlık) göre moleküler düzeyde karşılaştırılması yapılmamıştır.

Hastalık etmeni hem toprak hem de bulaşık üretim materyali ile taşınabilmektedir. Bu nedenle hastalığın inokulum kaynağının belirlenmesi oldukça güç olmaktadır. Hastalık daha çok bahçe koşullarında zarar oluşturduğundan hastalığın fidanlıklardan geldiği iddia edilmektedir. Özellikle hastalıkla bulaşık bu alanlar nedeniyle bahçe sahipleri ve fidan üreticilerinin mahkemelik davalarda karşı karşıya gelmesi sıkça rastlanılan bir durumdur. Ancak hem toprak hem de üretim materyali ile taşınan hastalık etmeninin esas inokulum kaynağını belirlemekte güçlüklerle karşılaşılmaktadır. Aynı zamanda uzun süren mahkeme aşamaları süresince hastalıkla bulaşık bitkiler üretim alanı içerisinde tutulduğundan Agrobacterium tumefaciens özellikle sulama suyu, toprak taşınması ile daha geniş alanlara yayılabilmektedir.

Bu çalışma kapsamında fidanlıklardan izole edilen izolatlarla üretici bahçesindeki hasta bitkilerden elde edilen izolatlar arasındaki benzerlik belirlenerek bulaşıklığın fidandan mı yoksa bahçe toprağından mı kaynaklandığı ortaya konarak mahkemelik davalara faydalı olabilmek amaçlanmıştır. Farklı bölgelerden ve farklı konukçulardan elde edilen izolatlar karşılaştırılarak izolatlar ve konukçu bitki arasındaki ilişki değerlendirilmiştir. Ayrıca izolat elde edilen bölgeler ile izolatlar arasında farklılık var mı sorusuna yorum getirilmeye çalışılmıştır.

\section{Materyal ve Metot}

\section{1. Çalışma Materyali}

Çalışmanın ana materyalini İzmir ve Burdur illerindeki fidanlıklardan, Adana ve Mersin illerinde ticari üretim yapılan meyve bahçeleri ve fidan üretimi ve satışının yapıldığı yerlerden 10 farklı konukçudan toplanan urlu örneklerden izole edilen 138 adet Agrobacterium tumefaciens izolatı ve referans izolatlar oluşturmuştur. Bunun dışında çeşitli kimyasallar, sarf malzeme ve saksılar da materyal olarak kullanılmıştır.

Ayrıca Çukurova Üniversitesi Ziraat Fakültesi Bitki Koruma Bölümü Bakteriyoloji Laboratuvarı kültür koleksiyonunda bulunan erikten izole edilen D9b, elmadan izole edilen Ma4b, kirazdan izole edilen K1e, kayısıdan izole edilen Ka1/2b (Aysan ve ark., 2003), gülden izole edilen Gül43 ve Gül55 (Aysan ve Sahin, 2003) kodlu Agrobacterium tumefaciens izolatları karşılaştırma kültürü olarak kullanılmıştır.

Fidanlıklardan hasta örnek toplamak için topraktan fidanların söküm zamanı olan Şubat ayı tercih edilirken meyve bahçelerinden hasta örnek toplamak için ise urların oluşmaya başladığı bahar aylarında ziyaret edilmesi tercih edilmiştir. 2008-2011 yılları arasında, Adana, Mersin ve İzmir illerindeki fidanlık, meyve bahçesi ve süs bitkisi serası olmak üzere yaklaşık 1000 dekarlık alan ziyaret edilmiştir. Fidanlıklardan 113, meyve bahçelerinden 20 ve süs bitkisi seralarından 15 urlu örnek olmak üzere toplam 148 hasta bitki toplanmıştır (Tablo 2).

Tablo 2. 2008-2011 yılları arasında farklı illerden toplanan bitki sayıları

Table 2. Plant numbers collected from different provinces between 2008-2011

\begin{tabular}{lllll}
\hline \multicolumn{2}{l}{ Toplanan Urlu Bitki Sayısı } & & \\
\hline Yer & Fidanlık & Meyve Bahçesi & Süs Bitkisi Üretim Yeri & Toplam \\
Izmir & 72 & - & - & 72 \\
Adana & 37 & 16 & 15 & 68 \\
Mersin & - & 4 & - & 4 \\
Burdur & 4 & - & - & 4 \\
Toplam & 113 & 20 & 15 & 148 \\
\hline
\end{tabular}

\subsection{Agrobacterium tumefaciens' in İzolasyonu ve Tanısı}

$\mathrm{Bu}$ çalışmada, araziden toplanan ve laboratuvarımıza posta yoluyla gönderilen 148 adet urlu örnekten, ur belirtisi göstermeyen trabzon hurması, kiraz ve kayısı köklerinden genel bakteriyolojik yöntemlere göre izolasyonlar yapılmıştır (Moore ve ark., 2001). Urlardan izolasyonlarda üç farklı besi yeri (King B, PDA ve 1A) 
kullanılmıştır. Ağırlıklı olarak kök ve gövde kısımlarında meydana gelen urlardan izolasyon örnekleri alınırken, henüz kuruma belirtisi göstermeyen taze, krem rengi ve aktif olan urlar seçilmiştir. Urlu örnekler üst kısmı soyularak alttaki canlı kısımlardan küçük parçalar alınmıştır. Altta kalan kısımda yer yer kıvrılmalar olduğu ve bunların tek bir odak noktasının bulunduğu gözlenmiş, bu beyaz renkli noktalara izolasyon materyali olarak kullanılmıştır. Urlu bitkilerin yanı sıra ur belirtisi göstermeyen trabzon hurması, kiraz ve kayısı örnekleri de alınarak izolasyon yapılmıştır. Urlu bitkilerde de olduğu gibi, üst kabuk dokusu kaldırıldı̆̆ında altta kalan dokunun kıvrılarak yuvarlak şekil aldığı görülmüş, bisturi ile bu kısımlar alınıp izolasyonda kullanılmıştır. Urlardan izolasyonlarda üç farklı besi yeri ,King B (Horuz ve Aysan, 2018), PDA ve 1A kullanılmıştır (Moore ve ark., 2001).

\subsection{Patojenite Testleri ve Re-İzolasyonlar}

Urlu örneklerden ve hastalık belirtisi göstermeyen dokulardan izole edilen bakterilerin patojenite yetenekleri domates (Solanum lycopersicum L.), kalonşe (Kalonchoe daigramontiana), ayçiçeği (Helianthus annus) fideleri ve havuç (Daucus carota) dilimlerinde testlenmiştir (Moore ve ark., 2001).İnokule edilen bitkiler iklim odasında $\left(25^{\circ} \mathrm{C}\right.$ ve 16 saat $1 s ̧ ı k$ ve 8 saat karanlık) 21 gün inkübe edildikten sonra ur varlığı/yokluğu yönünden değerlendirilmiştir (Minnemeyer ve ark., 1991). Ur oluşumu gözlenen bitkilerden yeniden izolasyon yapılarak reizolatlar elde edilmiş ve Koch Postulatlarının aşamaları tamamlanmıştır. Havuç dilimlerinde patojenite çalışmalarında, King B besiyerinde $25^{\circ} \mathrm{C}^{\prime}$ de 2 gün geliştirilmiş bakteri kültürü steril kürdanla havuç dilimlerinin yüzeyine inokule edilmiştir. Steril suyla nemlendirilmiş petriler $25^{\circ} \mathrm{C}$ 'de inkubasyona bırakılmış olup aralıklarla petrilere steril kağıtlar nemli kalacak şekilde steril saf su eklenmiştir. Petriler inokulasyondan 2 hafta sonra ur varlığı/yokluğuna göre değerlendirme yapılmıştır.

\subsection{Agrobacterium tumefaciens' in Klasik Yöntemlerle Tanısı}

Hastalık belirtisi göstermeyen hurma, kiraz, kayısı fidanlarından ve 148 urlu bitkiden izole edilen 138 Agrobacterium izolatının klasik yöntemlerle tanısı yapılmıştır. Sonuçları değerlendirmek için daha önceden Agrobacterium tumefaciens olarak tanılanmış altı referans izolat da kullanılmıştır. Kullanılan testler; 3-ketolaktoz üretimi, \% 2'lik $\mathrm{NaCl}$ 'de büyüme, $35^{\circ} \mathrm{C}$ 'de gelişme, litmus milk'de reaksiyon, eritritol ve melezitozdan asit oluşturma, malonik asit, L-tartarik asit ve mucic asitten alkali oluşturma, demir amonyum sitrat kullanımı, sitrat kullanımı, $\mathrm{PDA}+\mathrm{CaCO}_{3}$ besiyerinde asit temizleme, potasyum hidroksit testiyle gram reaksiyon ve oksidaz testidir (Moore ve ark., 2001).

\subsection{Agrobacterium tumefaciens'e Spesifik PCR (Polimerase Chain Reaction) ile İolatlartn Moleküler Tanist}

Agrobacterium tumefaciens izolatlarının DNA izolasyonu De Boer ve Ward (1995)'a göre yapılmıştır. Daha sonra \% 1'lik agaroz jel elektroforez ile total genomik DNA varlığı kontrol edilmiştir. İzole edilen DNA'lar $20^{\circ} \mathrm{C}$ 'de muhafaza edilmiştir. 6 farklı primer seti seçilen 36 izolat için kullanılmıştır (Tablo 3).

Tablo 3. Agrobacterium tumefaciens'e spesifik PCR primerleri

Table 3. PCR primers specific to Agrobacterium tumefaciens

\begin{tabular}{lll}
\hline Primerler & $\begin{array}{l}\text { DNA Bant Büyüklüğü } \\
\text { (bp) }\end{array}$ & Kaynak \\
\hline Tms2a: 5'-CGCCACACAGGGCTGGGGTAGGC-3' & 220 & $\begin{array}{l}\text { Pulawska ve } \\
\text { Sobiczewski, 2005 }\end{array}$ \\
Tms2b: 5'GGAGCAGTGCCGGGTGCCTCGGGA-3' & 480 & Eastwell \\
\hline VirA1: 5'-TTCAGTCGCGCAAGC AGT T-3' & & ark., 1995 \\
VirA2: 5'-CGGCAATTCGTATCACGGA -3' & & Dong ve ark., 1992 \\
\hline Wide1: 5'-AAG TCG TCG AGA TAC TGT TT -3' & 180 & \\
Wide2: 5'-TAT GAT ACC TTA AGC AGA TG -3' & & \\
\hline
\end{tabular}

PCR tüpüne DNA toplam hacmi $25 \mu$ olan reaksiyon karışımı olarak eklenmiştir (Sawada ve ark., 1995). Primerleri dizayn eden araştırıcılar tarafından belirlenen ve spesifik PCR programları kullanılarak amplifikasyonlar gerçekleştirilmiştir. Elde edilen PCR ürünlerinden jel elektroforezi yapılmıştır (Pionnat ve ark., 1999). Marker olarak 100 bp'lik ve 1 kb'lik DNA işaretleyicileri kullanılmıştır. Son aşamada jel oda sıcaklığında 
Geylani Yüzbaşıoglu \& Aysan Farklı Konukçu Bitkilerden İzole Edilen Agrobacterium tumefaciens İzolatlarının Fenotipik ve Genotipik Karakterizasyonu etidyum bromid ile boyanmış ve UV-transliminatörde görüntülenmiştir. Agrobacterium tumefaciens'e spesifik primerlerle yapılan PCR çalışmaları üç kez tekrarlanarak bantların tekrarlanabilir olduğu ortaya konmuştur.

\section{6. İolatlarm Genotipik Akrabalık Seviyelerinin Belirlenmesi}

Agrobacterium tumefaciens izolatları arasındaki genotipik akrabalığı araştırırken REP-PCR (Repetitive Extragenic Palindromic-PCR), ERIC-PCR (Enterobacterial Repetitive Intergenic Consensus-PCR), BOX-PCR (Box Element-PCR) ve PCR-RFLP (Restriction Fragment Length Polymorphism) yöntemlerinden faydalanılmıştır. On farklı konukçudan, dört farklı ilden, 2006-2011 yıllarında, 23'ü meyve bahçesinden, 22'si fidanlıktan, üçü gül üretim serasından izole edilen ve klasik testlerde farklılık gösteren 48 izolat seçilerek kullanılmıştır

REP-PCR primeri olarak REP 1R: 5'-IIIICGICGICATCIGGC-3've REP 2I: 5'-ICGICTTATCIGGCCTAC-3' primer çifti, ERIC-PCR primeri olarak ERIC 1R: 5'-ATGTAAGCTCCTGGGGATTCAC-3', ERIC 2: 5'AAGTAATGACTGGGGTGAGCG-3'primer çifti ve BOX-PCR primeri olarak BOX A1R 5'CTACGGCAAGGCGACGCTGACG-3' kullanılmıştır (Versalovic ve ark, 1994).

REP , ERIC-PCR ve BOX-PCR'da PCR tüpüne hacmi $25 \mu$ olan reaksiyon karışımı olarak eklenmiştir. BOXPCR'da ise PCR tüpüne (Rademaker ve Brujin, 1997). Tüplerin üzerine $10 \mu 1$ mineral yağ eklenerek tüpün ağzı sıkıca kapatılarak thermal cycler cihazına yerleştirilmiştir.

ERIC ve BOX-PCR programları Rademaker ve Brujin (1997)'e göre REP-PCR programı Nielsen ve ark., (2008)'a göre amplifikasyonlar gerçekleştirilmiştir. Elde edilen PCR ürünlerinden \% 2'lik agaroz jele yüklenmiş ve elektroforezde 100 volt akımda üç saat jel yürütülmüştür (Pionnnat ve ark., 1999). Marker olarak 100 bp'lik ve 1 kb'lik DNA işaretleyicileri kullanılmıştır. Son aşamada jel oda sıcaklığında etidyum bromid ile boyanmış ve UV-transliminatörde görüntülenmiştir. ERIC-PCR, REP-PCR, BOX-PCR çalışmaları üç kez tekrarlanarak bantların tekrarlanabilir olduğu ortaya konmuştur.

\subsection{RFLP (Restriction Fragment Length Polymorphizm)}

$\mathrm{Bu}$ yöntemde saf olarak çoğaltılmış bakteri kültürlerinden izole edilen DNA'ların restrüksiyon endonükleaz enzimleri ile kesilip agaroz jel elektroforez ortamında ayrıştırıldıktan sonra elde edilen farklı uzunluktaki DNA parçacıklarının oluşturduğu bantların analizine göre yapılmıştır. Metot, iki aşamada gerçekleştirilmiştir: Birinci aşamada, öncelikle FGPS6: 5'-GGAGAGTTAGATCTTGGCTCAG-3' FGPS1509': 5'AAGGAGGGGATCCAGCCGCA-3'primerleri ile izolatların PCR'1 yapılmıştır. İkinci aşamada, elde edilen PCR ürünü Oger ve ark., (1998)'nın önerdiği Hpa II, Alu I, Hae III enzimleri ile kesilerek izolatlar arası farklılık ve benzerlikler ortaya konmaya çalışılmıştır.

Oger ve ark., 1998'e göre hazırlanan ve PCR karışımı ve programı kullanılarak amplifikasyonlar gerçekleştirilmiştir. Elde edilen 10-12 $\mu \mathrm{l}$ PCR ürünleri 1X TAE tamponla hazırlanmış \% 2'lik agaroz jel elektroforezde 100 volt akımda üç saat yürütülmüştür (Pionnat ve ark., 1999). Marker olarak 100 bp'lik ve 1 kb'lik DNA işaretleyicileri kullanılmıştır. Son aşamada tanktan dikkatlice alınan jel oda sıcaklığında etidyum bromid ile boyanmış ve UV-transliminatörde görüntülenmiştir.

Bir sonraki aşama olan PCR ürünlerinin enzimle kesilmesi için, reaksiyon karışımları Oger ve ark., 1998'e göre hazırlanmıştır. PCR tüpüne toplam hacmi $15 \mu \mathrm{l}$ olan reaksiyon karışımı olarak eklenmiş ve thermal cycler cihazına yerleştirilmiştir. Üretici firmanın önerileri doğrultunda Alu I ve Hpa II (Fermantas) enzimleri içeren PCR tüpleri, 1 saat, Hae III (Fermantas-Fast Digest) içeren PCR tüpleri ise $5 \mathrm{dk} 37^{\circ} \mathrm{C}$ 'de thermal cycler cihazında inkübasyona bırakılmıştır.

Elde edilen enzimle kesilmiş PCR ürünlerinden 10-12 $\mu$ l alınıp 1X TAE tamponla hazırlanmış \% 2’lik agaroz jel elektroforezde 100 volt akımda üç saat yürütülmüştür (Pionnat ve ark., 1999). Marker olarak 100 bp'lik ve 1 kb'lik DNA işaretleyicileri kullanılmıştır. Son aşamada jel oda sıcaklığında etidyum bromid ile boyanmış ve böylece seçilen 48 izolat için bantlar UV-transliminatörde görüntülenmiştir.

\subsection{Genotipik Akrabalık Seviye Belirleme Analizlerinin Değgerlendirilmesi ve Dendogram Oluşturulması}

REP-PCR, ERIC-PCR, BOX-PCR ve PCR-RFLP yöntemleri sonucu 48 izolat için elde edilen bant profilleri ile SPSS Cluster analizine göre dendogram oluşturulmuştur. Dendogramda yer alan ve en az iki izolatın oluşturduğu filogenetik topluluk küme olarak tanımlanmıştır. Dendogram içinde diğer izolatlar ile ilişkisiz bireysel profilleri olan izolatlar ise terminolojiye göre özgü profil olarak adlandırılmıştır. Dendogramdaki küme sayısı ve özgü profilin toplamı genotip sayısı olarak ifade edilmiştir. Dendogramda yer alan izolatlar arasındaki benzerlik ilişkisi Tenover ve ark., (1997)'na göre yapılmıştır. 


\section{Araştırma Sonuçları ve Tartışma}

Yapılan çalışmada, biyokimyasal testler ve patojenite test sonuçlarına göre, 2008-2011 yılları arasında Adana, Mersin, Burdur ve İzmir illerinden toplanan on farklı konukçudan (erik, şeftali, kiraz, kayısı, elma, trabzon hurması, armut, gül, meşe, kalonşe) 174 adet bakteri izolatı elde edilmiş ve 138 izolatın patojen olduğu belirlenmiştir (Tablo 4).

\section{Tablo 4. Patojen olarak belirlenen Agrobacterium tumefaciens izolatlarının illere ve konukçulara göre dağılımı}

Table 4. Provinces and hosts of pathogenic Agrobacterium tumefaciens sytains

\begin{tabular}{lll}
\hline Yer & İzolat Sayısı & Konukçu \\
\hline İzmir & 78 & Erik, kayısı, kiraz, elma, armut \\
Adana & 54 & $\begin{array}{l}\text { Erik, kayısı, kiraz, şeftali, armut, trabzon } \\
\text { hurması, kalonşe, meşe, gül }\end{array}$ \\
Mersin & 4 & Kayısı, şeftali \\
Burdur & 4 & Trabzon hurması, şeftali \\
\hline Toplam & $\mathbf{1 3 8}$ & \\
\hline
\end{tabular}

Çalışmada kullanılan 138 adet re-izolatın tümü biyokimyasal testlerde karşılaştırma amaçlı kullanılan altı referans kültür de benzer reaksiyonlar vermiştir. Sadece $\mathrm{PDA}+\mathrm{CaCO}_{3}$ besi yerinde dört izolatın (Bad.17, Bad.25, Ala1, Ala2 kodlu izolatlar) asit temizleme yeteneği pozitif olduğu belirlenmiştir. Sonuç olarak morfolojik, fizyolojik ve biyokimyasal test sonuçlarına göre tüm izolatlar Agrobacterium tumefaciens olarak tanılanmıştır.

Sözkonusu 138 Agrobacterium tumefaciens izolatın ve 6 referans izolatın DNA'sı izole edilmiş ve \% 1'lik agoroz jel elektroforezde yürütülerek total genomik DNA varlığı tespit edilen bantlarla saptanmıştır.

Agrobacterium izolatlarının türe spesifik primerlerle yapılan moleküler tanısında, tüm izolatları tanıyan tek bir primer seti mevcut değildir. Bu nedenle 3 farklı primer seti kullanmıştır. Agrobacterium tumefaciens'e spesifik PCR testlerinde Tms2a-Tms2b, VirA1-VirA2 ve Wide1-Wide2 primer çiftlerinin kullanımının uygun olduğu saptanmıştır (Şekil 1).

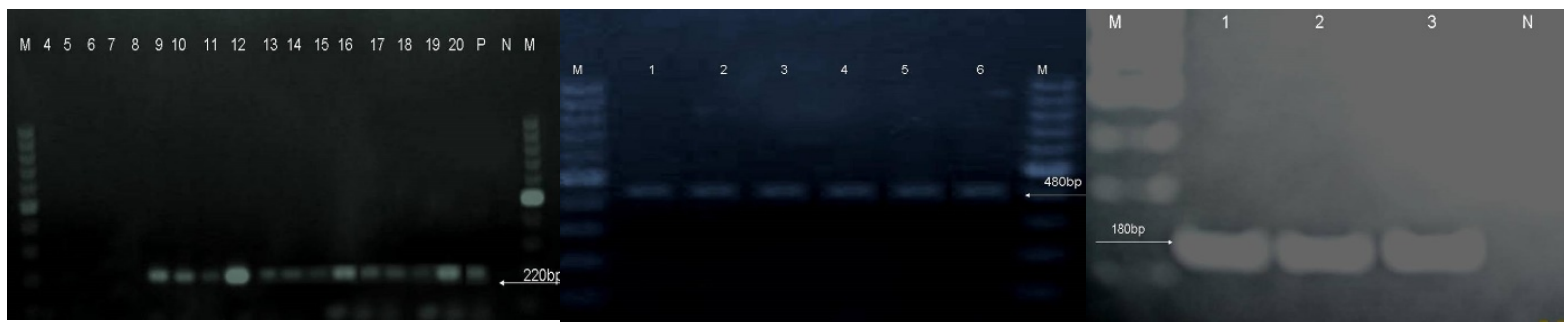

a

$\mathrm{b}$

$\mathrm{c}$

Figure 1. Bands in PCR study with Tms2a and Tms2b(a), VirA1 and VirA2(b), Wide1 and Wide2(c) primers Şekil 1. Tms2a ve Tms2b(a), VirA1 ve VirA2(b), Wide1 ve Wide2(c) primerleriyle yapılan PCR çalışması sonucunda ortaya çıkan bantlar

Tms2a-Tms2b primerleri kullanılarak 123 izolat 220 bp'lik bant, VirA1-VirA2 primerleri kullanılarak 124 izolat 480 bp'lik ve Wide1-Wide2 primerleri kullanılarak 135 izolat 180 bp'lik bant oluşturmuştur. Wide1-Wide2 primerleri izolatlarımızın \% 94'ünü tanırken, VirA1-VirA2 primerleri izolatlarımızın \% 86'sını, Tms2a-Tms2b primerleri izolatlarımızın \% 85'ini tanımıştır. Bizim çalışmamızda bu üç primer seti içinden en başarılı olanın Wide1-Wide2 primer seti olduğu saptanmıştır.

Seçilen primerlerle 144 izolatın PCR'1 $3 \mathrm{kez}$ pozitif sonuç alınacak şekilde yapılarak jel görüntülemede görüntülenmiştir. Ancak tüm primerler tüm izolatlarda amplifikasyon göstermemiştir. Toplamda 144 Agrobacterium izolatının 101 tanesi üç primer çiftiyle yapılan PCR'da pozitif sonuç verirken 36 izolat iki farklı primer çiftiyle yapılan PCR'da pozitif sonuç vermiştir. Sadece yedi izolatımız tek bir primer çiftiyle yapılan PCR'da bant oluşturmuştur. Bu sonuca göre, 2008-2011 yılları arasında Adana, Mersin, Burdur ve İzmir illerinden 
toplanan on farklı konukçudan izole edilen 138 adet izolat ve 6 referans kültürün spesifik PCR testi ile tanısı desteklenerek Agrobacterium tumefaciens oldukları teyit edilmiştir.

Tüm izolatlar arsından seçilen 48 adet Agrobacterium tumefaciens izolatlarıla yapılan REP-PCR (Şekil 2), ERIC-PCR (Şekil 3), BOX-PCR (Şekil 4) ve PCR-RFLP'de (Şekil 5) agaroz jelde farklı bantların oluşturduğu polimorfizm belirlenmiştir. Bu çalışmada kullanılan primerler bakterilerin genomik DNA'ları üzerinde farklı bölgelere bağlanarak amplifiye olmuş ve agaroz jelde farklı büyüklükte bant oluşumuna neden olmuştur.

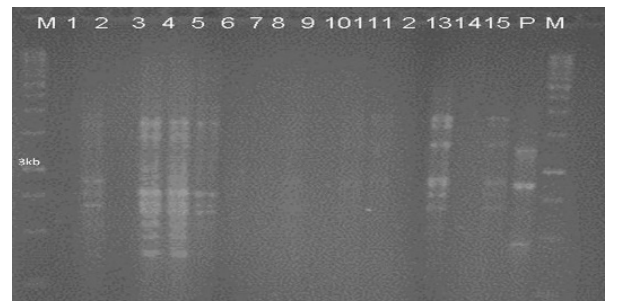

Figure 2. Bands in REP-PCR genetic profiling technique

Şekil 2. REP-PCR genetik profilleme tekniği ile oluşan bantlar

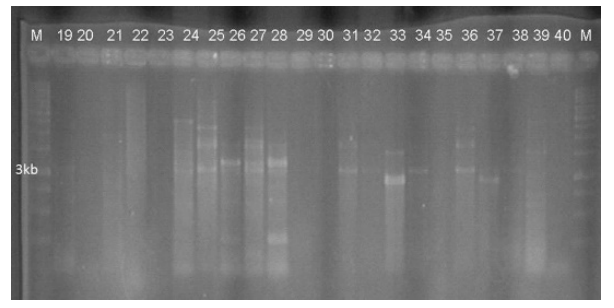

Figure 3. Bands in ERIC-PCR genetic profiling technique

Şekil 3. ERIC-PCR genetik profilleme tekniği ile oluşan bantlar

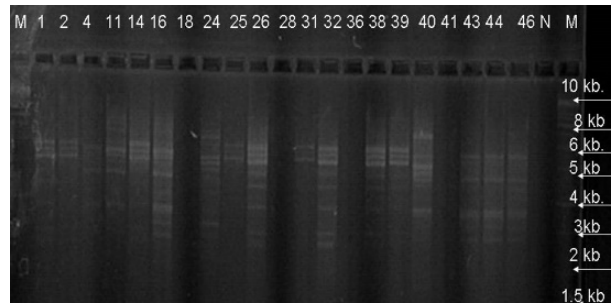

Figure 4. Bands formed by BOX-PCR genetic profiling technique Şekil 4. BOX-PCR genetik profilleme tekniği ile oluşan bantlar

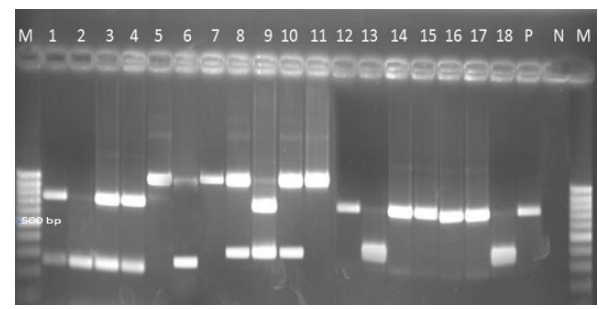

Figure 5. Bands formed by PCR-RFLP genetic profiling technique Şekil 5. PCR-RFLP genetik profilleme tekniği ile oluşan bantlar

Genotipik karakterizasyonun sağlıklı ve kesin olabilmesi için tüm genotipik analizlerin verileriyle meydana gelen dendogramın incelenip yorumlanması gerekmektedir. Genotipik olarak birbirine en yakın akraba olan iki izolat (C-1 ve C-2) birbirine \% 97.54 oranında benzerlik gösterirken aralarındaki farklılık \% 2.46 oranındadır. Birbirine en uzak izolatlar bile \% 96.4 oranında birbirine benzerlik göstermiştir. Bu büyük benzerlik oranı tüm izolatların aynı tür olduğunun da göstergesidir.

Dendogramda toplamda 8 küme, 26 özgü profil olmak üzere 34 genotip ortaya çıkmıştır. Dendogramın kümeleşme oranı yani küme içindeki izolat sayısının toplam izolat sayısına oranı 22/48 8 (0.458)'dir. 
Dendogramda yer alan en büyük küme yedi en küçük küme ise iki izolattan oluşmaktadır. Dendogramda yer alan kümeler ve özgü profiller Şekil 6'da verilmiştir.

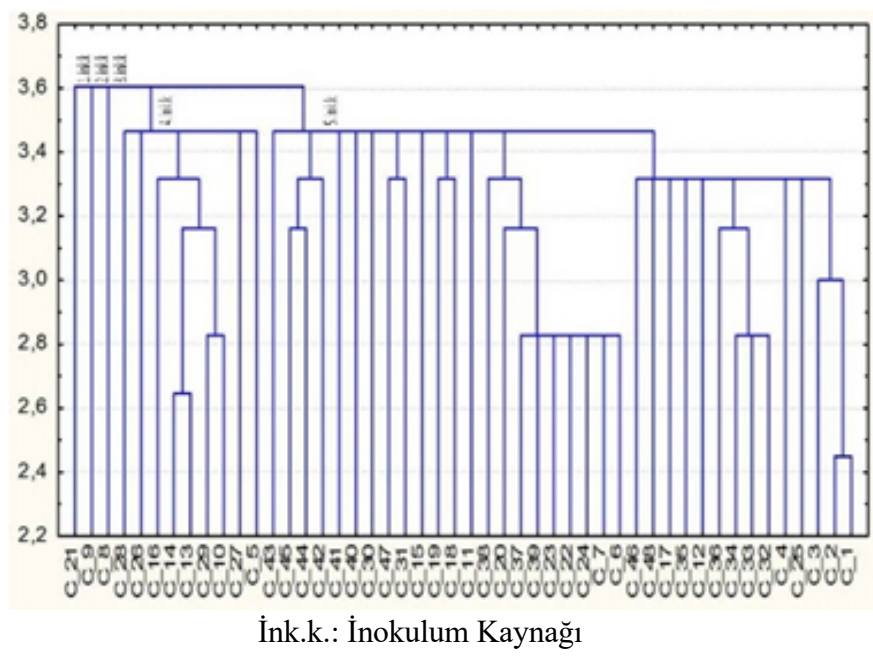

Figure 6. Dendogram formed by isolates of Agrobacterium tumefaciens in all molecular tests

Şekil 6. Tüm moleküler testlerde Agrobacterium tumefaciens izolatlarının oluşturduğu dendogram

Bu bulgular incelendiğinde; aynı il, köy veya bahçeden alınan örneklerin dendogramın farklı bölümlerinde yer alabildiği, çok farklı yerlerden alınan örneklerin ise aynı alt grup veya aynı kümede olabileceği saptanmıştır. Özellikle aynı kümede bulunan izolatlar birbirine son derece yakın akraba olan aynı inokulum kaynağından bulaşmış ve yayılmış örnekler olarak değerlendirilebilir. Fakat tüm kayısı veya şeftali izolatları bir kümede veya bir alt grupta toplanmamıştır. Bu nedenle izolatlar-konukçu bazında bir ilişki olmadığı belirlenmiştir.

Dendogramda iki ana grup ve bunlardan farklı olarak üç izolatın bulunduğu üç özgü profil görülmektedir. Bu özgü profillerin elde edildiği yer incelendiğinde biri Mersin (C-8) ve diğer ikisi İzmir ilinden (C-9 ve C-21) izole edilen izolatlardır. Bunların farklı bir inokulum kaynağından yayılmış olabileceği düşünülmüş̧ür.

Birinci ana grupta yer alan tek alt grupta bulunan dokuz izolatın altısı Adana'dan üçü İzmirden izole edilmiştir (Tablo 5).

İkinci ana grupta iki farklı alt grubun yer alması iki farklı inokulum kaynağı olabileceği düşüncesini akla getirmektedir. Benzer şekilde, ikinci ana grubun ikinci alt grubunda yer alan 14 izolatın 11'i Adana'dan, ikisi Mersin ve biri İzmir'den elde edilmiştir. Bu izolatların dokuzu bahçeden beşinin fidanlıktan izole edilmiş olması fidanlık-bahçe arasındaki bulaşmayı göstermektedir.

Böylece toprak kökenli olan bu etmen fidanlık toprağına bulaştıktan sonra o toprakta yetiştirilen tüm bitkilere (farklı tür veya çeşitlere) kolaylıkla bulaşabilmekte ve farklı bölgelere yapılan fidan ticaretiyle yeni alanlara inokulum taşınabilmektedir. Bu durum çok uzun yıllardır bilinmesine rağmen bu çalışmada hastalığın bulaşık fidanlarla yeni alanlara geldiği iddiası moleküler testlerle kanıtlanmıştır. 
Farklı Konukçu Bitkilerden İzole Edilen Agrobacterium tumefaciens İzolatlarının Fenotipik ve Genotipik Karakterizasyonu

Tablo 5. Genotipik karakterizasyona göre oluşturulan dendogramda yer alan kümeler ve bu kümelere dahil olan özgü profiller

Table 5 Clusters in the dendogram formed according to genotypic characterization and specific profiles included in these clusters

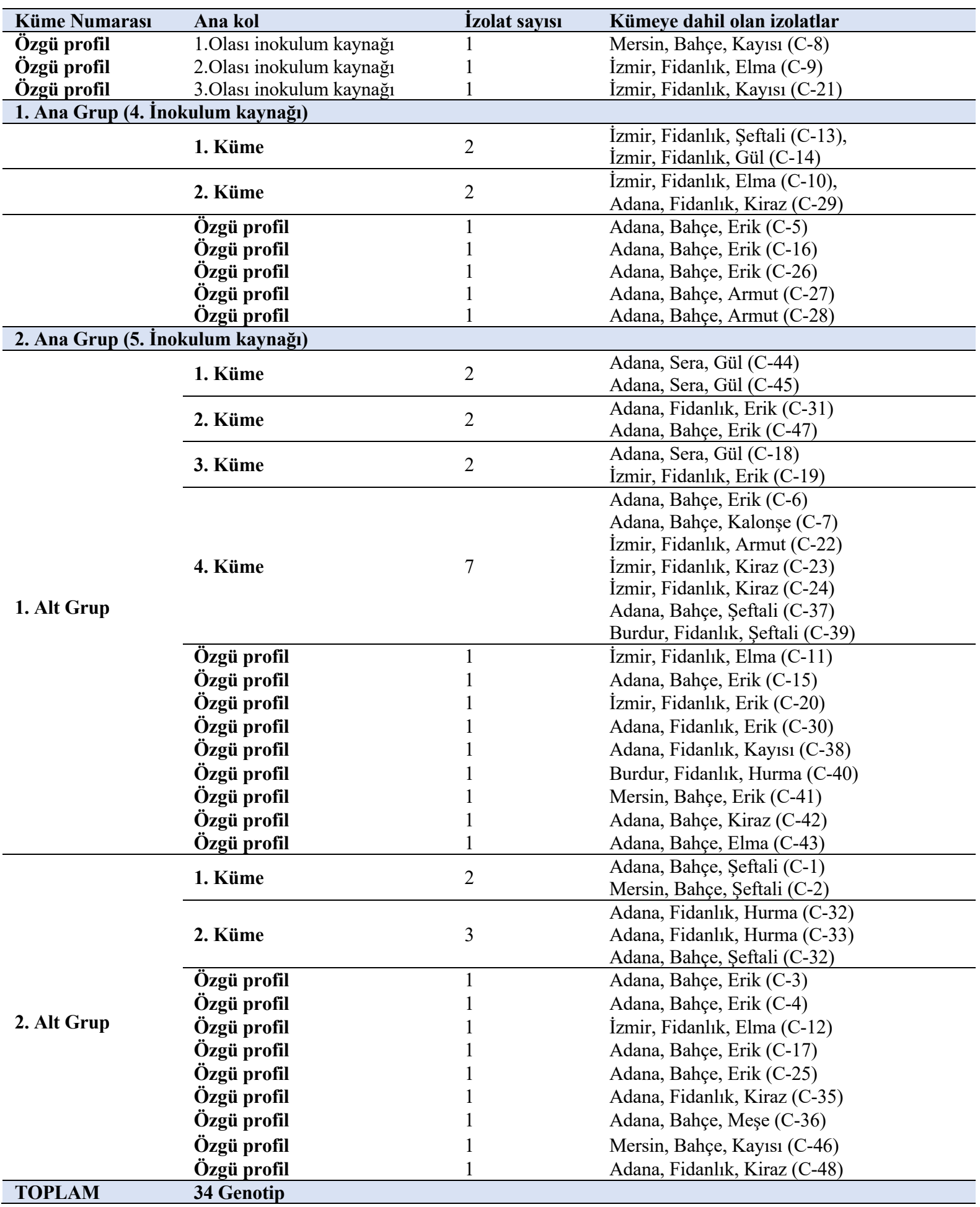

\section{Sonuç}

Çok sayıda farklı konukçuda ur oluşturabilen, kendine özgü hastalık oluşturma mekanizması nedeniyle izolasyonu diğer bakteriyel etmenlerden daha zor olan Agrobacterium tumefaciens bakterisinin dört farklı ilden (Adana, Burdur, İzmir ve Mersin) toplanan urlu bitkilerden izolasyonu, patojenitesi, klasik bakteriyolojik teknikler ve moleküler tanısıyla izolatlar arasındaki genotipik ilişkinin ortaya konması amacıyla bu çalışma yapılmıştır. 
Çalışma sonucunda elde edilen izolatlar 13 farklı biyokimyasal ve fizyolojik teste tabi tutulmuş olup sadece $\mathrm{PDA}+\mathrm{CaCO}_{3}$ besi yerinde asit temizleme testinde izolatlar arasında farklılık görülmüştür. Bölge izolatları ve karşılaştırma kültürlerini içeren tüm izolatlar arasında sadece üç izolat bu besi yerinde asit oluşturmuştur. Morfolojik olarak farklı görülen bir çok izolatın ise biyokimyasal ve fizyolojik testlerde farklılık göstermediği belirlenmiştir. Sonuçlar referans izolatların sonuçlarıyla da karşılaştırılmış ve birbiriyle uyumlu olduğu gözlenmiştir.

İzolatların patojenitesi domates (Solanum lycopersicum L.), kalonşe (Kalonchoe daigremontiana), ayçiçeği (Helianthus annus) fidelerinde ve havuç (Daucus carota) dilimlerinde testlenmiştir. Referans izolatlarda dahil olmak üzere izolatların tamamı havuç ve kalonşe fidelerinde ur oluştururken bu sayı ayçiçeği fidelerinde 83, domates fidelerinde ise $77^{\prime}$ 'dir. Patojenite çalışmalarıyla tüm izolatların ur oluşturabildiği saptanmıştır. Bu durum konukçular arasında patojenite açısından farklar olduğunun göstergesidir. Özellikle taze urlardan elde edilen izolatlar 2 haftada ur oluşturmaya başlamışken urların gelişim hızı da diğerlerine oranla daha fazladır. Bazı izolatların ise 2 ayda çok küçük urlar oluşturabildiği saptanmıştır. En başarılı sonuçlar havuç dilimleri ve kalonşe bitkilerinde gözlenmiştir.

Çalışmanın moleküler testlerle ilgili kısmında 144 izolatın Agrobacterium cinsine (VirA1-VirA2 ve Wide1Wide2 primer çiftleri) ve Agrobacterium tumefaciens'e (tms2a-tms2b primer çifti) spesifik PCR'ı yapılmıştır. Başlangıçta kullanılan altı çift primerden üçünde beklenen bantlar oluşmamış ve başarılı olan üç primer çiftinin kullanımına karar verilmiştir. Ancak bu üç primer de bazı izolatlarla amplifikasyon göstermemiştir.

Çalışmada tüm izolatlar içinde 123 adedi tümör büyüklügünü düzenleyen genlerle kontrol edilen, Tiplazmiddeki T-DNA bölgesinindeki tms bölgesini tanıyan Agrobacterium tumefaciens'i diğer Agrobacterium'lardan kesin olarak ayıran tms2a ve tms2b primerleri ile bant oluşturmuştur. Ti-plazmidin ribozomal kısmında yer alan ve virulenslik genlerinden VirA ile kontrol edilen $16 \mathrm{~S}$ ve $23 \mathrm{~S}$ rDNA bölgelerini ve bu bölgeler arasında kalan intergenik bölgeyi tanıyan VirA1 ve VirA2 primerleri ile yapılan PCR'da 124 izolat bant oluşturmuştur. Ti ve Ri plazmidlere özgü Wide1 ve Wide2 primerleriyle ise 135 izolat bant oluşturmuştur. Böylece klasik test sonuçları desteklenmiştir. Ek olarak Agrobacterium tumefaciens ile yapılan PCR çalı̧̧malarında en iyi sonucu veren primerlerin Ti-plazmide özgü primerler olduğu, kromozomal DNA'ya özgü PCR primerlerinin Rhizobium'larla Agrobacterium'lar arasındaki farkı kaçırabileceği tespit edilmiştir. Ayrıca çalışmada kullanılan PCR primerleri opin tiplerini belirlemede yeterli olmamıştır.

İzolatlar arasında seçim yapılmış ve 48 izolat seçilerek, sadece bakterilerde kullanılan genotipik profilleme teknikleri olan PCR-RFLP, Rep-PCR, Eric-PCR ve Box-PCR metodlarına tabi tutulmuştur. Temel prensipleri aynı olan, program ve primerlerde farklılık gösteren bu üç testin dendogramları ayrı ayrı yapılmış ve daha sonra tek bir dendogram haline getirilerek yorumlanmıştır. Bu testleri uygulama aşamasında Rep-PCR'ın izolatları kümelemede en etkili teknik olduğu düşünülmüsşür. Bu testlerin ardından PCR-RFLP analizi uygulanmış olup burada amaç belli gruplara ayrılan izolatların restriksiyon enzimleri olan Hpa II, Alu I, Hae III ile kesilerek farklı yerlerde amplifikasyon elde edilmesiyle izolatların çok daha fazla sayıda alt gruba ayrılmasıdır ancak bu enzimlerle yapılan uygulama çok etkili olamamıştır.

$\mathrm{Bu}$ çalışma kapsamında farklı konukçulardan elde edilen izolatların birbirine olan genotipik akrabalıkları ile hastalığın bir konukçudan diğerine geçiş olasılıkları yani izolatlar ve konukçu arasındaki ilişki ortaya konmuştur. Tüm dendogram sonuçları birlikte yorumlanacak olursa; Farklı yıllarda, farklı konukçulardan ve farklı illerden alınan örneklerden izole edilen bakterilerin aynı grup hatta, aynı alt grupta yer aldığı yani genetik olarak benzerlik gösterdikleri saptanmıştır. Bununla birlikte, aynı bahçeden alınan örneklerden elde edilen iki izolatın farklı gruplarda yer aldığı belirlenmiştir. Bu örnekler bize hastalığın, bu kadar farklı bölgelerden illere yayılmasının ancak bulaşık fidan ile taşınmayla mümkün olabildiğini bir kez daha göstermiştir.

\section{Teșekkür}

Bu çalışma doktora tezinden hazırlanmış olup Çukurova Üniv. Bap tarafından ZF2009D22 numaralı proje ile desteklenmiştir. 


\section{Kaynakça}

Anonım (2006). Gıda Tarım ve Hayvancılık Bakanlığı Teknik Talimatnamesi, (Erişim tarihi: 25 Aralık 2013)

Anonım (2011). Fao statistics, www.fao.org, (Erişim tarihi: 23 Aralık 2013)

Anonım (2012). TUIK verileri,www.tuik.gov.tr, (Erişim tarihi: 25 Aralık 2013)

Aysan, Y., Sahın, F., Mirık, M., Donmez, M.F. and Tekman, H. (2003). First report of crown gall of apricot (Prunus armeniaca) caused by Agrobacterium tumefaciens in Turkey. Plant Pathology, 52 (6): 793-795.

Aysan, Y., Sahin, F. ( 2003). An outbreak of crown gall disease on rose caused by Agrobacterium tumefaciens in Turkey. Plant Pathology, 52 (6):780-783

Bozkurt, I. A., Soylu, S., 2011. Hatay İli Elma Bahçelerinde Agrobacterium tumefaciens'in Neden Olduğu Kök Boğazı uru Hastalığının Belirlenmesi. Türkiye 4. Bitki Koruma Kongresi 28-30 Haziran 2011, Sayfa, 315, Kahramanmaraş.

De Boer, S. H., Ward, L.J. (1995). PCR detection of Erwinia carotovora subsp. atroseptica associated with patoto tissue. Phytopathology, 85: 854-858.

De Cleene, M., De Ley, J. (1976). The host range of crown gall. Bot. Rev, 42: 389-466.

Dong, L. C., Sun, C. W., Thies, K. L., Luthe, D. S., Graves, C. H. (1991). Use of polymerase chain reaction to detect pathojenic strains of. Agrobacterium. Phytopathology, 82: 434-439.

Eastwell, K. C., Willıs, L. G., Cavileer, T. D. (1995). A rapid and sensitive method to detect Agrobacterium vitis in grapewine cuttingns using the Polimerase chain reaction. Plant Disease, 79: 822-827.

Horuz S. ve Aysan.Y., (2018). Kabakgil Tohumlarında Karpuz Bakteriyel Fide Yanıklı̆̆1 ve Meyve Lekesi Hastalığı Etmeni Acidovorax citrulli’nin Varlığının BelirlenmesindeKullanılabilecek Uygun Yöntem(ler)in Saptanması. Tekirdağ Ziraat Fak. Dergisi. 15(3). S.38-43.

Karaca, I. (1977). Fitobakteriyoloji ve Bakteriyel Hastalıklar. Ege Üniversitesi, Ziraat Fakültesi Yayınları, No: 294, 270 s.

Lipincott, J. A., Lipincott, B. B. (1975). The genus Agrobacterium and plant tumorigenesis. Annual Rev. Microbiol. $29: 377-405$.

Lipincott, J. A., Lipincott, B. B., Starr, M. P. (1980). The genus Agrobacterium. (In: Star MP editor) Phytopathogenic Bacteria, $842-855$. springer- Verlag, New York.

Lipincott, J. A., Lipincott, B. B., Starr, M. P. (1983). The genus Agrobacterium In Starr MP et al (eds) The procaryotes A Handbook on Habitats, Isolation and Identification of Bacteria, Springer Verlag, New York, pp. 842-855.

Minnemeyer, S., Lighrfoot, L., Matthysse, A., G. (1991). A semiguantitatue bioassay for relative virulence of Agrobacterium tumefaciens strains on Bryophyllum daigoromontiana. Jour. Bacteriology, 173: 7723-7724.

Moore, L. W., Bouzar, H., Burr, T. (2001). Agrobacterium. P: 17-35 In Laboratory Guidek for Identification of Plant Pathogenic Bacteria, 3rd.Ed., (Schaad, N.W., Jones, J.B., Chun, W. editors), American Phytopathological Press, St. Parl, Minnesota.

Nielsen, K.M., Jhonsen,P., Ben Sasson, D., Daffonchio, (2008). Release and persistense of extracelülar DNA in the open environment. Envion. Biosafety research, 6:37-53.

Oden,S., 1991. İzmir ve İstanbul İllerinde Önemli Süs Bitkilerinde Görülen Bakteriyel Hatalıklar ve Etmenlerin Saptanması Üzerine Araştırmalar. Ege Üniversitesi, Fen bilimleri Entstitüsü, Bitki Koruma anabilim dalı, Doktara Tezi, 84 sayfa

Oger, P., Desaux, Y., Petıt, A., Gardon, L., Mancaeau, C., Chomel, C., Nesme, X. (1998). Validity sensitivity and resolution limit of thePCRRFLP analysis of the rrs (16S rRNA gene) as a tool to identfy soil-borne and plant -associated bacterial populations. Genet. Sel. Evol., 30 suppl. 1: $311-321$

Peluso, R., Ra1o, A., Morra, F., Zoina, A. (2003). Physiolgical, biochemical and molecular analyses of Italian collection of Agrobacterium tumefaciens strain Eurepean Journal of Plant Pathology, 109: 291-300.

Pınnat, S., Keller, H., Herıcher, D., Bettachini, A.,Dessaux, Y., Nesme, X., Poncet, C. (1999). Ti plazmids from Agrobacterium characterize rookstock clones that initiated a spread of crown gall disease in mediterranean countries. Apllied and Enviromental Microbiology, Vol, 65, No. 9: 4197-4206.

Pulawska, J. and Sobiczewsk1, P. (2005). Devolepment of a semi-nested PCR based method for sensitive detection of tumorigenic Agrobacterium in soil. J. Appl. Microbiology, 98 (3): 710-721.

Rademaker, J. L. W., Brujin, F. J. (1997). Characterization and classification of microbes by REP-PCR genomic finger printing and computer asisted pattern analysis. Journal Applied Bacteriology, 68: 728-738.

Sawada, H., Jekı, H., Matsuda, I. (1995). PCR Detection Ti and Ri Plazmids from Phytopathogenic Agrobacterium strains. Applied and Environmental Microbiology, February: 828-831.

Slater, S.C., Barry, S. G., Goodner, B., Setubal, J. C., Farrand, S.K., Nester, E. W., Burr, J., Banta, L., Dickerman, A.W., Paulsen, I., Otten, L., Suen, G., Welch, R., Almeida, E., Godsy, E., Heisel, S. (2009). Genome sequences of three Agrobacterium biovars help elucidate the evoltion of multicchromosome genomes in bacteria. Journal of Bacteriology, Vol. 191, No. 8: 2501-2511. 
Smith E.F., Townsend, C. O. (1907). A plant tumor of bacterial origin. Science, Apr, 26;25(643:671-3)

Soylu, S., Bozkurt, İ, A. (2019) Elma kök uru hastalığı etmeni Rhizobium radiobacter'e karşı epifitik ve endofitik bakteri izolatlarının antogonistik potansiyellerinin belirlenmesi. Jotaf. Cilt. 16, Sayı 3. 348-361.

T. C. Gıda, Tarım ve Hayvancılık Bakanlığı. Zirai Karantina Yönetmeliği (2009).

Tan, B. S, Yabuk1, J., Matsumoto, S., Kageyama, K., Fuku1, H. (2003). PCR primers for identification of opine types of Agrobacterium tumefaciens in Japan. Journal of General Plant Pathology, 69 (4): 258-266.

Tenover, F. C. Arbeit, R. D., Goorıng. R.U. (1997). How to select and interpret molcular strain typing methods for epidemiological studies of bacterial infections: a review for health care epidemiologists. Infect Control Hosp. Epidemiology, 18: 426-439

Versalovic, J., Schneıder, M, De brujn, F. J., Lupsk1, J. R. (1994). Genomic fingerprintig of bacteria using repetetive sequence-based polimerase chain reaction. Methods in Molecular and Cellular Biology, 5: 25-40. 